\title{
Chloroflexus aggregans sp. nov., a Filamentous Phototrophic Bacterium Which Forms Dense Cell Aggregates by Active Gliding Movement
}

\author{
SATOSHI HANADA, ${ }^{*}$ AKIRA HIRAISHI, ${ }^{2}$ KEIZO SHIMADA, ${ }^{1}$ AND KATSUMI MATSUURA ${ }^{1}$ \\ Department of Biology, Tokyo Metropolitan University, Hachioji, Tokyo 192-03, ${ }^{1}$ and Laboratory of \\ Environmental Biotechnology, Konishi Co., Ltd., Sumida, Tokyo $130,{ }^{2}$ Japan
}

\begin{abstract}
Two strains of thermophilic photosynthetic bacteria, designated MD-66 ${ }^{\mathrm{T}}$ ( $\mathrm{T}=$ type strain) and YI-9, were isolated from bacterial mats in two separate hot springs in Japan. These new isolates were phenotypically similar to Chloroflexus aurantiacus in some respects. They were thermophilic filamentous photosynthetic bacteria that grew well at $55^{\circ} \mathrm{C}$ either anaerobically as photoheterotrophs or aerobically as chemoheterotrophs. They exhibited gliding motility, produced bacteriochlorophylls $a$ and $c$, contained chlorosomes, and required thiamine and folic acid as growth factors. However, isolates MD-66 ${ }^{\mathrm{T}}$ and YI-9 had the ability to rapidly form mat-like dense aggregates of filaments, an ability which has not been observed in any $C$. aurantiacus strain. Carbon source utilization tests revealed that unlike $C$. aurantiacus, the new isolates did not utilize acetate, citrate, ethanol, or glycylglycine. An analysis of the carotenoid components revealed that isolates $\mathrm{MD}^{-66^{\mathrm{T}}}$ and YI-9 contained mainly $\gamma$-carotene and $\mathrm{OH}-\boldsymbol{\gamma}$-carotene glucoside fatty acid esters. These isolates also contained only trace amounts of $\beta$-carotene, which is a major carotenoid component ( $28.4 \%$ of the total carotenoids) in C. aurantiacus. The results of DNA hybridization studies suggested that the new strains were genetically distinct from C. aurantiacus (levels of similarity, 9 to 18\%), and 16S rRNA sequence comparisons showed that strain MD- $66^{\mathrm{T}}$ was related to $C$. aurantiacus at a similarity level of $92.8 \%$. On the basis of our data, we propose that a new Chloroflexus species should be created for our new isolates; the name of this new species is Chloroflexus aggregans, and the type strain is strain MD-66 (= DSM 9485).
\end{abstract}

The first filamentous anoxygenic phototrophic bacteria were discovered by Pierson and Castenholz in thermophilic environments (25). These organisms were described as members of a new genus and species, Chloroflexus aurantiacus, and strain $\mathrm{J}-10$-fl, which was isolated from a Japanese hot spring, was designated the type strain of this species (26). Following this description, Gorlenko and coworkers found members of two apparently related mesophilic filamentous phototrophic genera in freshwater habitats, the genera Chloronema (4) and "Oscillochloris" (9). These organisms exhibited gliding motility and contained pigment-bearing vesicles called "chlorosomes" (32). The group containing the phototrophic bacteria includes representatives of another genus, the genus Heliothrix, as described by Pierson et al. (29). Members of the genus Heliothrix have not been isolated in pure culture yet, but they are known to lack chlorosomes. The results of a $5 \mathrm{~S}$ rRNA sequence analysis showed that Heliothrix oregonensis is phylogenetically related to Chloroflexus aurantiacus.

A phylogenetic analysis based on $16 \mathrm{~S}$ rRNA sequence data revealed that Chloroflexus aurantiacus is not closely related to any other phototrophic bacteria and forms a remarkably deep branch on the common line of eubacterial descent (23). Consequently, the filamentous phototrophs are now placed in a group called the "multicellular filamentous green bacteria" $(24,36)$ or the "filamentous anoxygenic phototrophs" (27).

Chloroflexus strains and their relatives have been detected and observed in hot springs, freshwater lakes, and marine environments $(1-3,7,8,16,19,30,33,34)$. However, most strains have not been isolated in axenic culture, and molecular

* Corresponding author. Mailing address: Department of Biology, Tokyo Metropolitan University, 1-1 Minamiohsawa, Hachioji, Tokyo 192-03, Japan. Phone: (81) 42677 2582. Fax: (81) 42677 2559. Electronic mail address: shanada@yamabuki.comp.metro-u.ac.jp. phylogenetic data are not available for any organisms except Chloroflexus aurantiacus, Heliothrix oregonensis, and the recently described isolate Oscillochloris trichoides DG-6 (16, 26, 29).

We isolated several strains of thermophilic filamentous phototrophic bacteria from various hot springs in Japan by using an improved isolation method (11). Most of these new isolates were assigned to $C$. aurantiacus on the basis of morphological, physiological, and chemotaxonomic characteristics and DNADNA hybridization data. However, two of the isolates, designated MD- $66^{\mathrm{T}}$ ( $\mathrm{T}=$ type strain) and YI-9, clearly differed from Chloroflexus aurantiacus in that they formed mat-like dense aggregates. The results of a preliminary DNA-DNA hybridization assay suggested that there is a distinct genetic distance between these two isolates and Chloroflexus aurantiacus.

In this study, we characterized these aggregate-forming strains by determining their morphological, physiological, and genetic properties. We found that the new strains represent a distinct species of the genus Chloroflexus, and we propose the name Chloroflexus aggregans sp. nov. for this taxon.

\section{MATERIALS AND METHODS}

Bacterial strains and growth conditions. Strain MD- $66^{\mathrm{T}}$ (= DSM 9485) was isolated from bacterial mats in an outflow $\left(57^{\circ} \mathrm{C}, \mathrm{pH} 7.0\right)$ of the Okukinu Meotobuchi hot spring in Tochigi Prefecture, Japan. This spring contains sodium chloride $(18 \mathrm{mM})$ and sodium bicarbonate $(3 \mathrm{mM})$ as its major salts and trace amounts of sulfide, and the bacterial mat consisted of a dark green layer of filamentous and unicellular cyanobacteria covered with bright yellow streamers (length, approximately $1 \mathrm{~cm}$ ) that were composed of filamentous green bacteria. Strain YI-9 (= DSM 9486) was isolated from the Yufuin hot spring $\left(67^{\circ} \mathrm{C}, \mathrm{pH}\right.$ 8.2) in Oh-ita Prefecture, Japan. These strains were isolated out by using PE medium supplemented with $1.5 \%$ agar. This medium contained (per liter) $0.5 \mathrm{~g}$ of sodium glutamate, $0.5 \mathrm{~g}$ of sodium succinate, $0.5 \mathrm{~g}$ of sodium acetate, $0.5 \mathrm{~g}$ of yeast extract (Difco), $0.5 \mathrm{~g}$ of Casamino Acids (Difco), $0.5 \mathrm{~g}$ of $\mathrm{Na}_{2} \mathrm{~S}_{2} \mathrm{O}_{3} \cdot 5 \mathrm{H}_{2} \mathrm{O}$, $0.38 \mathrm{~g}$ of $\mathrm{KH}_{2} \mathrm{PO}_{4}, 0.39 \mathrm{~g}$ of $\mathrm{K}_{2} \mathrm{HPO}_{4}, 0.5 \mathrm{~g}$ of $\left(\mathrm{NH}_{4}\right)_{2} \mathrm{SO}_{4}, 1 \mathrm{ml}$ of a vitamin mixture, and $5 \mathrm{ml}$ of a basal salt solution. The $\mathrm{pH}$ of the medium was adjusted to 7.5 with $\mathrm{NaOH}$. The vitamin mixture contained (per $100 \mathrm{ml}$ ) $100 \mathrm{mg}$ of 
nicotinic acid, $100 \mathrm{mg}$ of thiamine hydrochloride, $5 \mathrm{mg}$ of biotin, $50 \mathrm{mg}$ of $p$-aminobenzoic acid, $1 \mathrm{mg}$ of vitamin $\mathrm{B}_{12}, 50 \mathrm{mg}$ of calcium pantothenate, $50 \mathrm{mg}$ of pyridoxine hydrochloride, and $50 \mathrm{mg}$ of folic acid. The basal salt solution contained (per liter) $1.11 \mathrm{~g}$ of $\mathrm{FeSO}_{4} \cdot 7 \mathrm{H}_{2} \mathrm{O}, 24.65 \mathrm{~g}$ of $\mathrm{MgSO}_{4} \cdot 7 \mathrm{H}_{2} \mathrm{O}, 2.94 \mathrm{~g}$ of $\mathrm{CaCl}_{2} \cdot 2 \mathrm{H}_{2} \mathrm{O}, 23.4 \mathrm{~g}$ of $\mathrm{NaCl}, 111 \mathrm{mg}$ of $\mathrm{MnSO}_{4} \cdot 4 \mathrm{H}_{2} \mathrm{O}, 28.8 \mathrm{mg}$ of $\mathrm{ZnSO}_{4} \cdot 7 \mathrm{H}_{2} \mathrm{O}, 29.2 \mathrm{mg}$ of $\mathrm{Co}\left(\mathrm{NO}_{3}\right)_{2} \cdot 6 \mathrm{H}_{2} \mathrm{O}, 25.2 \mathrm{mg}$ of $\mathrm{CuSO}_{4} \cdot 5 \mathrm{H}_{2} \mathrm{O}, 24.2 \mathrm{mg}$ of $\mathrm{Na}_{2} \mathrm{MoO}_{4} \cdot 2 \mathrm{H}_{2} \mathrm{O}, 31.0 \mathrm{mg}$ of $\mathrm{H}_{3} \mathrm{BO}_{3}$, and $4.53 \mathrm{~g}$ of trisodium EDTA. Enrichment cultures were established by using the same medium and were incubated in screw-cap tubes or bottles at $55^{\circ} \mathrm{C}$ under incandescent light (approximately $\left.30 \mathrm{~W} / \mathrm{m}^{2}\right)(11)$

Electron microscopy. Phototrophically grown cells were harvested and embedded in $2 \%$ agar (27). The agar was cut into $1-\mathrm{mm}^{3}$ cubes and fixed for $4 \mathrm{~h}$ at room temperature with $2.5 \%$ glutaraldehyde in Kellenberger buffer ( $\mathrm{pH} 6.8$ ) supplemented with $0.05 \%$ ruthenium red $(15,18)$. The cubes were washed and postfixed with $1 \% \mathrm{OsO}_{4}$ in buffer containing $0.05 \%$ ruthenium red at $4^{\circ} \mathrm{C}$ for $6 \mathrm{~h}$. They were then washed again and placed in $0.5 \%$ uranyl acetate in water for $1 \mathrm{~h}$ at room temperature. After washing and dehydration, the cubes were embedded in Spurr embedding medium (17). Thin sections were stained with $5 \%$ uranyl acetate for $20 \mathrm{~min}$ at $45^{\circ} \mathrm{C}$ and with $0.002 \%$ lead citrate for $1 \mathrm{~min}$ at room temperature (37). Micrographs were taken with a JEOL model JEM-1010 electron microscope operating at $80 \mathrm{kV}$.

Physiological tests. For nutritional experiments we used the media used for Chloroflexus aurantiacus, as previously described by Madigan et al. (21), with some modifications. The basic medium contained (per liter) $0.38 \mathrm{~g}$ of $\mathrm{KH}_{2} \mathrm{PO}_{4}$, $0.39 \mathrm{~g}$ of $\mathrm{K}_{2} \mathrm{HPO}_{4}, 0.5 \mathrm{~g}$ of $\mathrm{Na}_{2} \mathrm{~S}_{2} \mathrm{O}_{3} \cdot 5 \mathrm{H}_{2} \mathrm{O}, 0.5 \mathrm{~g}$ of $\left(\mathrm{NH}_{4}\right)_{2} \mathrm{SO}_{4}, 1 \mathrm{ml}$ of the vitamin mixture, and $5 \mathrm{ml}$ of the basal salt solution (see above). The final $\mathrm{pH}$ of the medium was adjusted to 7.5. For each nutritional test performed under aerobic conditions, we used $5 \mathrm{ml}$ of autoclaved basic medium containing an organic carbon source at a final concentration of $0.25 \%(\mathrm{wt} / \mathrm{vol})$ in a $30-\mathrm{ml}$ L-shaped tube closed with a silicon sponge stopper; the tubes were incubated under aerobic conditions in the dark at $55^{\circ} \mathrm{C}$. For each nutritional test performed under anaerobic conditions, we used a $30-\mathrm{ml}$ screw-cap tube filled with basic medium supplemented with a filter-sterilized sulfide-bicarbonate solution $\left(\mathrm{Na}_{2} \mathrm{~S} \cdot 9 \mathrm{H}_{2} \mathrm{O}\right.$ at a final concentration of $0.05 \%$ [wt/vol], $\mathrm{NaHCO}_{3}$ at a concentration of $0.03 \%$ [wt/vol]) and an organic carbon source at a concentration of $0.25 \%$ (wt/vol); the tubes were incubated in the light or in the dark at $55^{\circ} \mathrm{C}$. All organic carbon sources were neutralized and sterilized before they were added. Vitamin requirements were determined by using eight vitamin combinations, each of which lacked one of eight vitamins (nicotinic acid, thiamine hydrochloride, biotin, $p$-aminobenzoic acid, vitamin $\mathrm{B}_{12}$, calcium pantothenate, pyridoxine hydrochloride, folic acid). An organic medium containing $2 \%$ vitamin-free Casamino Acids (Difco) was used in this test, and the final results were determined after three serial transfers.

Spectroscopy and pigment analyses. Cells were collected from 2-day cultures in PE medium and then were washed and disrupted by sonication at $140 \mathrm{~W}$ for $3 \mathrm{~min}$ in MOPS-potassium-magnesium buffer (0.01 M MOPS [morpholinepropanesulfonic acid]- $\mathrm{NaOH}, 0.1 \mathrm{M} \mathrm{KCl}, 0.001 \mathrm{M} \mathrm{MgCl}_{2} ; \mathrm{pH} 7.0$ ). The absorption spectra of ultrasonically disrupted cells in buffer were determined with a Shimadzu model UV-160 spectrophotometer. Pigments were extracted with chloroform-methanol $(3: 1, \mathrm{vol} / \mathrm{vol})$ and were analyzed by reverse-phase high-performance liquid chromatography (HPLC) by using methanol as the solvent (35).

Genetic properties. Genomic DNA was purified by the method of Marmur (22). The guanine-plus-cytosine $(\mathrm{G}+\mathrm{C})$ content was determined by performing HPLC of nuclease P1 hydrolysates of genomic DNA (13). DNA-DNA hybridization was performed by the quantitative dot blot hybridization method with photobiotin labeling and colorimetric detection $(5,13)$. 16S rRNA-specific DNA was amplified by PCR and was sequenced directly by the cycle sequencing method modified for automated fluorescence detection $(12,14)$.

Nucleotide sequence accession numbers. The 16S rRNA gene sequences of Chloroflexus aggregans MD- $66^{\mathrm{T}}$ and Chloroflexus aurantiacus $\mathrm{J}-10-\mathrm{fl}^{\mathrm{T}}$ determined in this study have been deposited in the DDBJ, EMBL, and GenBank data libraries under accession numbers D32255 and D38365, respectively. The GenBank and EMBL accession numbers for the 16S rRNA sequences used for comparison in the evolutionary distance matrix analysis are as follows: Bacteroides fragilis, M11656; Chlorobium limicola, M31769; Chlorobium tepidum, M58468; Clostridium ramosum, M23731; Escherichia coli, M24828; Heliobacterium chlorum, M11212; Herpetosiphon aurantiacus, M34117; Methanohalophilus mahii, M59133; Paracoccus denitrificans, X69159; Rhodobacter capsulatus, M34129; Thermomicrobium roseum, M34115; and Thermotoga maritima, M21774.

\section{RESULTS}

Morphology. The cells of the cluster-forming strains formed unbranched multicellular filaments of indefinite length. The diameters of full-grown filaments ranged from 1.0 to $1.5 \mu \mathrm{m}$ (Fig. 1). Septa were observed with a phase-contrast microscope, and the lengths of the individual cells in the filaments ranged from 2 to $6 \mu \mathrm{m}$. Granular inclusions were found commonly.

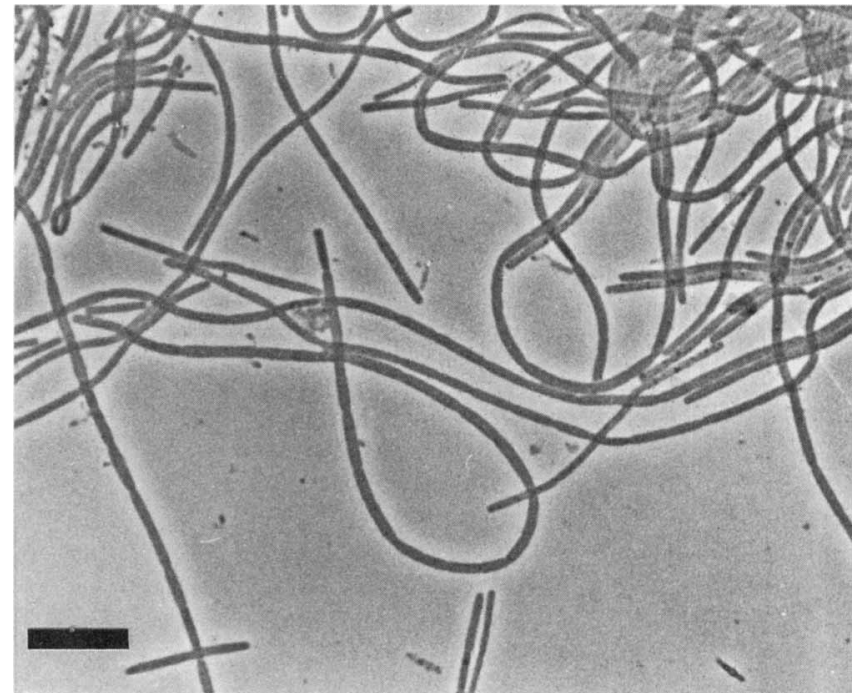

FIG. 1. Phase-contrast photomicrograph of strain MD- $66^{T}$ cells showing septa in filaments. Cells in the stationary growth phase were grown phototrophically at $55^{\circ} \mathrm{C}$ and $30 \mathrm{~W} / \mathrm{m}^{2}$ in PE medium. Bar $=10 \mu \mathrm{m}$.

Electron microscopic observations of ultrathin sections (Fig. 2a) showed that the cells of strain MD- $66^{\mathrm{T}}$ were 0.5 to $0.6 \mu \mathrm{m}$ wide. Septa were distinguished, and the lengths of individual cells ranged from 2 to $5 \mu \mathrm{m}$. Vesicular structures, presumably chlorosomes, were observed along the cytoplasmic membrane in the cytoplasm. No sheaths were observed (Fig. 2b).

Photosynthetic pigments. The cells of strains MD- $66^{\mathrm{T}}$ and YI-9 were green or greenish brown when the organisms were grown phototrophically in PE medium. Ultrasonically disrupted cells in buffer had absorption maxima at 464, 740, 803, and $868 \mathrm{~nm}$, and a shoulder at around $510 \mathrm{~nm}$ (Fig. 3), which indicates that carotenoids and bacteriochlorophylls $a$ and $c$ were present. This spectrum resembles that of Chloroflexus aurantiacus. An HPLC analysis revealed that the carotenoid components of the new isolates were mainly $\gamma$-carotene and $\mathrm{OH}-\gamma$-carotene glycoside fatty acid esters and that there was a trace amount of $\beta$-carotene (data not shown). When cultures were grown aerobically in $5-\mathrm{ml}$ portions of $\mathrm{PE}$ medium in $30-\mathrm{ml} \mathrm{L}$-shaped tubes shaken vigorously in the dark, the cells of the new isolates were reddish brown or orange because of the production of carotenoids and small amounts of bacteriochlorophylls even in the early log phase. The concentration of bacteriochlorophyll $c$ was approximately $0.5 \mathrm{nM}$ when the optical density at $620 \mathrm{~nm}$ of an aerobic culture of one of the new isolates was 0.05 . Under parallel conditions cultures of Chloroflexus aurantiacus $\mathrm{J}-10-\mathrm{fl}^{\mathrm{T}}$ were light pink in the early log phase because of the presence of small amounts of carotenoids and no bacteriochlorophyll (no bacteriochlorophyll $c$ was detected when the optical density at $620 \mathrm{~nm}$ of the culture was 0.05 ), as described previously by Fuller and Redlinger (6).

Active cell aggregation. When strain MD- $66^{\mathrm{T}}$ cells were grown with illumination, they formed mat-like dense aggregates that appeared to be "green balls" (Fig. 4). Aggregation was observed within 20 to $30 \mathrm{~min}$ each time that the cells were dispersed by shaking. The most rapid aggregation occurred at temperatures around $55^{\circ} \mathrm{C}$, which was the optimum temperature for growth of this organism. Since the aggregation that occurred was dependent on illumination or the oxygen supply, it could be considered active aggregation. This aggregation was probably due to the gliding motility of the filaments, which was 

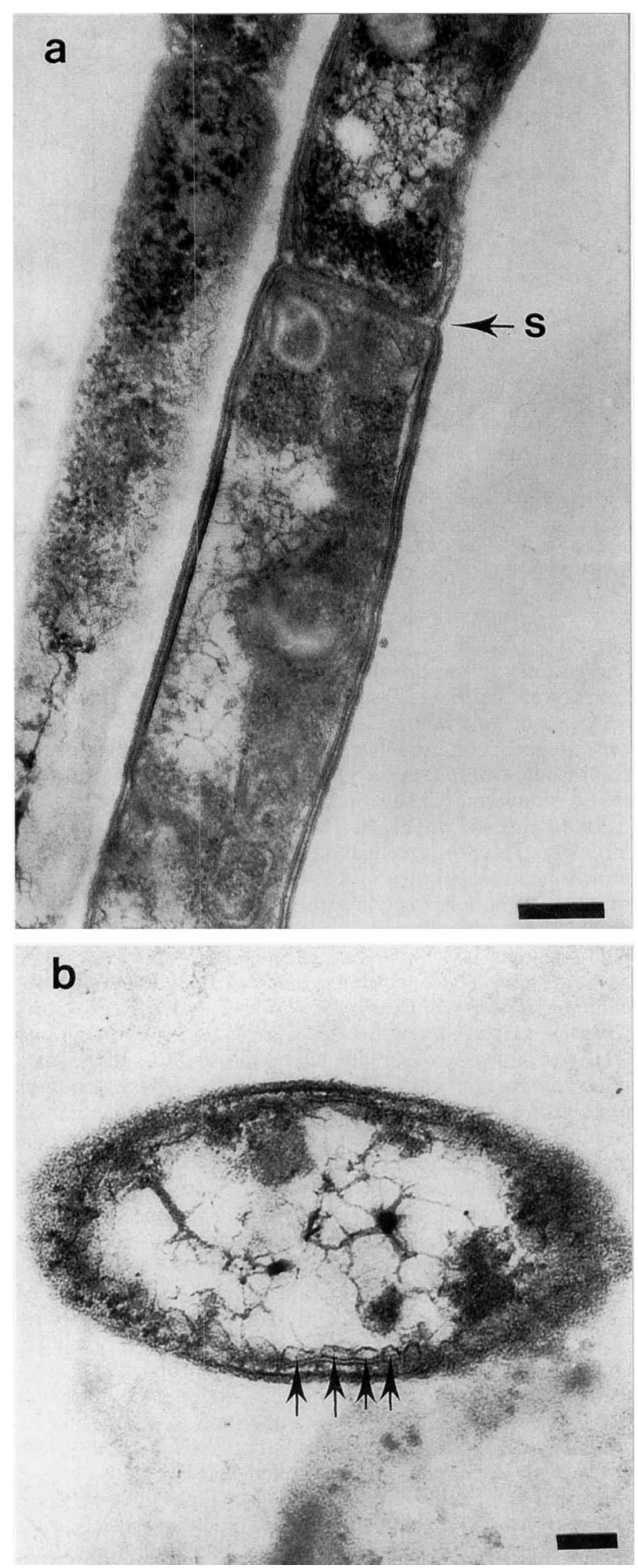

FIG. 2. Electron micrographs of ultrathin sections of strain MD- $66^{\mathrm{T}}$ cells poststained with uranyl acetate and lead citrate. (a) Longitudinal section of a filament. S, septum. Bar $=200 \mathrm{~nm}$. (b) Cross section showing chlorosomes inside the cytoplasmic membrane (arrows). Bar $=100 \mathrm{~nm}$.

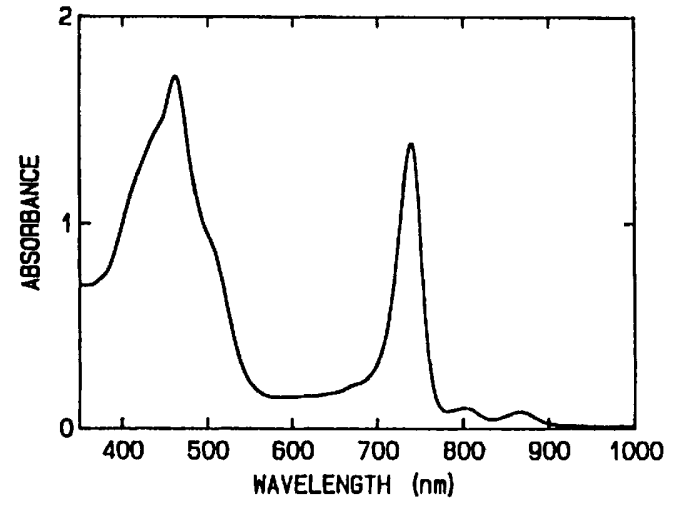

FIG. 3. Absorption spectrum obtained with strain MD- $66^{\mathrm{T}}$ cells grown under anaerobic conditions in the light in PE medium. The cells were ultrasonically disrupted in MOPS-sodium-magnesium buffer.

observed on the surface of a glass slide under a microscope, and the maximum rate was 1 to $3 \mu \mathrm{m} / \mathrm{s}$ at $55^{\circ} \mathrm{C}$. Details about the motility of Chloroflexus aggregans and the formation of mat-like dense aggregates by this organism will be described elsewhere.

Physiological and other characteristics. Strains MD- $66^{\mathrm{T}}$ and YI-9 were able to grow either anaerobically as photoheterotrophs or aerobically as chemoheterotrophs, like Chloroflexus aurantiacus. These strains grew at $\mathrm{pH}$ values ranging from 7.0 to 9.0. The optimum temperature for growth was between 50 and $60^{\circ} \mathrm{C}$. Both strains required thiamine and folic acid as growth factors. Table 1 shows the carbon sources utilized by these strains. Under anaerobic, light conditions, both strains utilized a wide variety of organic substrates. The highest growth rates and greatest cell yields were obtained in media containing yeast extract or Casamino Acids as the carbon source. In contrast, strains MD- $66^{\mathbf{T}}$ and YI-9 did not utilize most simple organic compounds as carbon sources under aerobic, dark conditions. Only yeast extract and Casamino Acids supported growth under aerobic conditions. Under anaerobic conditions in the dark, none of the substrates tested supported growth. Photoautotrophic growth with sulfide or thiosulfate as the electron donor was not observed with either strain.

Genetic properties. The DNA base compositions of the new isolates as determined by HPLC were 56.7 to $57.0 \mathrm{~mol} \% \mathrm{G}+\mathrm{C}$. These values are 2 to $3 \%$ higher than the values reported previously for Chloroflexus aurantiacus strains (26). The previously published values, however, were determined by the buoyant density method. Therefore, we determined the $\mathrm{G}+\mathrm{C}$ base

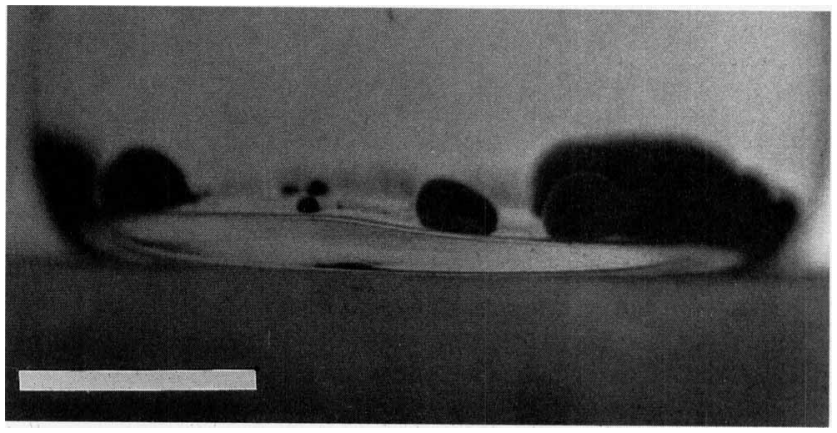

FIG. 4. Mat-like dense aggregates of strain MD- $66^{\mathbf{T}}$ cells growing in the bottom of a 200-ml screw-cap bottle containing PE medium under phototrophic conditions. $\operatorname{Bar}=2 \mathrm{~cm}$. 
TABLE 1. Utilization of organic compounds by Chloroflexus aggregans strains under various conditions ${ }^{a}$

\begin{tabular}{|c|c|c|c|c|c|c|}
\hline \multirow{4}{*}{ Carbon source } & \multicolumn{6}{|c|}{ Utilization by: } \\
\hline & \multicolumn{3}{|c|}{ Strain MD- $66^{\mathrm{T}}$} & \multicolumn{3}{|c|}{ Strain YI-9 } \\
\hline & \multicolumn{2}{|c|}{$\begin{array}{l}\text { Anaerobic } \\
\text { conditions }\end{array}$} & \multirow{2}{*}{$\begin{array}{c}\text { Aerobic } \\
\text { conditions }\end{array}$} & \multicolumn{2}{|c|}{$\begin{array}{l}\text { Anaerobic } \\
\text { conditions }\end{array}$} & \multirow{2}{*}{$\begin{array}{r}\text { Aerobic } \\
\text { condition }\end{array}$} \\
\hline & Light & Dark & & Light & Dark & \\
\hline Glutamate & + & - & - & + & - & - \\
\hline Aspartate & + & - & - & + & - & - \\
\hline Glycylglycine & - & - & - & - & - & - \\
\hline Acetate & $\pm^{b}$ & - & - & - & - & - \\
\hline Pyruvate & - & - & - & - & - & - \\
\hline Lactate & + & - & - & + & - & - \\
\hline Succinate & + & - & - & + & - & - \\
\hline Malate & + & - & - & + & - & - \\
\hline Butyrate & + & - & - & - & - & - \\
\hline Citrate & $\pm^{b}$ & - & - & $\pm^{b}$ & - & - \\
\hline Glucose & + & $\pm^{c}$ & - & + & $\pm^{c}$ & - \\
\hline Fructose & $\pm^{b}$ & - & - & $\pm^{b}$ & - & - \\
\hline Mannitol & $\pm^{b}$ & - & - & $\pm^{b}$ & - & - \\
\hline Methanol & $\pm^{c}$ & - & - & $\pm^{c}$ & - & - \\
\hline Ethanol & $\pm^{b}$ & - & - & - & - & - \\
\hline Glycerol & $\pm^{b}$ & - & - & - & - & - \\
\hline Yeast extract & ++ & - & ++ & ++ & - & ++ \\
\hline Casamino Acids & ++ & - & + & ++ & - & + \\
\hline $\mathrm{HCO}_{3}{ }^{-}$ & - & - & - & - & - & - \\
\hline
\end{tabular}

${ }^{\alpha}$ Relative growth after 3 days of incubation in vitamin-containing medium (see Materials and Methods) was assessed by determining whether the cell yield was comparable to that obtained with yeast extract $(++)$ or was significantly less than that obtained with yeast extract $(+)$. - , carbon source did not support growth.

${ }^{b}$ Faint growth was observed.

c Initial growth occurred, but sustained growth was not observed.

ratios of two strains of Chloroflexus aurantiacus $\left(\mathrm{J}-10-\mathrm{f}^{\mathrm{T}}\right.$ and OK-70-fl) by HPLC. The values which we obtained for Chloroflexus aurantiacus $\mathrm{J}-10-\mathrm{fl}^{\mathrm{T}}$ and OK-70-fl (56.9 and 57.1 mol\%, respectively) were similar to the values obtained for the new isolates.

The results of DNA-DNA hybridization studies indicated that the two new strains were closely related to each other and could be clearly distinguished from Chloroflexus aurantiacus (Table 2). The relative level of homology between MD-66 ${ }^{\mathrm{T}}$ and YI-9 was approximately $80 \%$, while the levels of homology between the new strains and Chloroflexus aurantiacus strains were approximately 9 to $18 \%$.

The sequences of 16S rRNA genes enzymatically amplified from strain MD- $66^{\mathrm{T}}$ and Chloroflexus aurantiacus $\mathrm{J}-10-\mathrm{fl}^{\mathrm{T}}$ were determined by direct automated sequencing. The sequences which we examined corresponded to positions 28 to 1,491 in the Escherichia coli sequence and represented $95 \%$ of the entire $16 \mathrm{~S}$ rRNA gene. The $16 \mathrm{~S}$ rRNA sequence of

TABLE 2. Levels of DNA homology between Chloroflexus aggregans and Chloroflexus aurantiacus strains

\begin{tabular}{|c|c|c|c|}
\hline \multirow{2}{*}{ Strain } & \multicolumn{3}{|c|}{$\begin{array}{l}\text { \% DNA homology with genomic } \\
\text { DNA from: }\end{array}$} \\
\hline & $\begin{array}{l}\text { Strain } \\
\text { J-10-f1 }\end{array}$ & $\begin{array}{l}\text { Strain } \\
{\text { MD- } 66^{\mathrm{T}}}^{-}\end{array}$ & $\begin{array}{c}\text { Strain } \\
\text { YI-9 }\end{array}$ \\
\hline Chloroflexus aurantiacus $\mathrm{J}-10-\mathrm{f}^{\mathrm{T}}$ & 100 & 10 & 16 \\
\hline Chloroflexus aurantiacus OK-70-fl & 98 & 14 & 18 \\
\hline Chloroflexus aggregans MD- $66^{\mathrm{T}}$ & 10 & 100 & 103 \\
\hline Chloroflexus aggregans YI-9 & 9 & 73 & 100 \\
\hline
\end{tabular}

Chloroflexus aurantiacus $\mathrm{J}-10-\mathrm{fl}^{\mathrm{T}}$ has been reported previously by Oyaizu et al. (23), but there were some undetermined regions in the data of these authors. Since in phylogenetic analyses of closely related species such a lack of information could easily lead to errors in classification, we decided to determine the sequence of Chloroflexus aurantiacus $\mathrm{J}-10-\mathrm{fl}^{\mathrm{T}}$ in this study.

The level of sequence similarity between strain MD- $66^{\mathrm{T}}$ and Chloroflexus aurantiacus was $92.8 \%$. Table 3 shows the evolutionary distances among representative members of bacteria as determined by the neighbor-joining method (31). A phylogenetic tree was reconstructed on the basis of the distance matrix data (Fig. 5). Strain MD-66 ${ }^{\mathrm{T}}$ formed a cluster with representatives of the green nonsulfur bacteria, a phylogenetic group defined by Woese (38) whose closest relative is Chloroflexus aurantiacus.

\section{DISCUSSION}

Our new isolates, strains MD- $66^{\mathbf{T}}$ and YI-9, are thermophilic, filamentous, phototrophic bacteria which grow well at $55^{\circ} \mathrm{C}$ either anaerobically as photoheterotrophs or aerobically as chemoheterotrophs and inhabit freshwater hot springs. These organisms exhibit gliding motility, produce bacteriochlorophylls $a$ and $c$, contain chlorosomes, and require thiamine and folic acid as growth factors. In these respects, the new strains are similar to Chloroflexus aurantiacus $(20,26)$.

However, our data revealed marked phenotypic differences between the new strains and Chloroflexus aurantiacus. The most distinctive property of the new organisms is their ability to rapidly form mat-like dense cell aggregates. Whenever aggregated cells were dispersed by shaking, dense aggregates formed again within 20 to $30 \mathrm{~min}$, with the energy required supplied by photosynthesis or respiration. Chloroflexus aurantiacus OK-70-fl tends to aggregate in tubes containing liquid medium under anaerobic conditions, but this aggregate formation is not rapid, unlike that observed with the new isolates. The rapid aggregation which we observed seemed to be linked to the fast gliding rate of the cells, which was determined on the surface of a glass slide with a microscope; the maximum gliding rate was 1 to $3 \mu \mathrm{m} / \mathrm{s}$ at $55^{\circ} \mathrm{C}$. The gliding rate of the new isolates is approximately 100 times higher than the gliding rates of Chloroflexus aurantiacus strains (the gliding rates of strain $\mathrm{J}-10-\mathrm{fl}^{\mathrm{T}}$ filaments on $1.5 \%$ agar were 0.01 to $0.04 \mu \mathrm{m} / \mathrm{s}$ ) and 10 times higher than the gliding rates of Heliothrix oregonensis F-1, which also forms clumps rapidly and has gliding rates of 0.1 to $0.4 \mu \mathrm{m} / \mathrm{s}(26,28)$.

Morphologically, the new isolates form unbranched multicellular filaments of indefinite length, like Chloroflexus aurantiacus. However, the cells of the new isolates are significantly wider than the cells of the type strain of Chloroflexus aurantiacus (J-10-fl) and slightly wider than the cells of strain OK-70-fl. The carbon source utilization tests revealed that unlike Chloroflexus aurantiacus (21), the new isolates do not utilize acetate, citrate, ethanol, or glycylglycine. Our analysis of carotenoid components revealed that the new isolates contain mainly $\gamma$-carotene and its derivatives, as well as trace amounts of $\beta$-carotene, while $\beta$-carotene is a major carotenoid component (28.4\% of the total carotenoids) in Chloroflexus aurantiacus (10). In addition, the quinone compositions of the new isolates and Chloroflexus aurantiacus differed, as the new isolates produced a small but significant amount of menaquinone 4 in addition to the predominant homolog, menaquinone 10 (11).

The $\mathrm{G}+\mathrm{C}$ contents of the DNAs of the new isolates are 56.7 to $57.0 \mathrm{~mol} \%$, values which are similar to the values obtained for Chloroflexus aurantiacus $\mathrm{J}-10-\mathrm{fl}^{\mathrm{T}}$ and $\mathrm{OK}-70-\mathrm{fl}$ (56.9 and 
TABLE 3. Evolutionary distance matrix for a collection of bacterial 16S rRNA sequences, including the sequence of Chloroflexus aggregans obtained by the neighbor-joining method ${ }^{a}$

\begin{tabular}{|c|c|c|c|c|c|c|c|c|c|c|c|c|c|}
\hline \multirow[b]{2}{*}{ Species } & \multicolumn{13}{|c|}{ Evolutionary distance $^{b}$} \\
\hline & 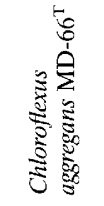 & 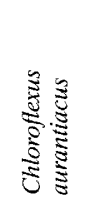 & 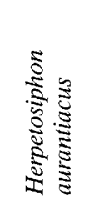 & 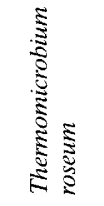 & 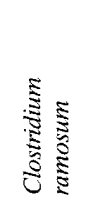 & 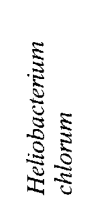 & 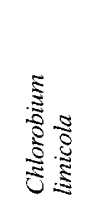 & 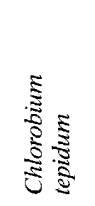 & 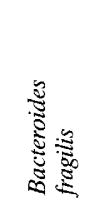 & 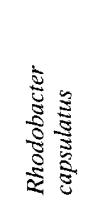 & 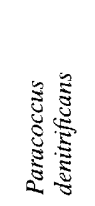 & 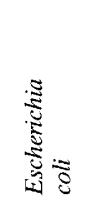 & 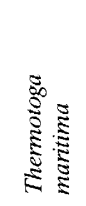 \\
\hline Herpetosiphon aurantiacus & 0.1776 & 0.1677 & & & & & & & & & & & \\
\hline Thermomicrobium roseum & 0.1986 & 0.1956 & 0.2006 & & & & & & & & & & \\
\hline Clostridium ramosum & 0.2515 & 0.2375 & 0.2285 & 0.2246 & & & & & & & & & \\
\hline Heliobacterium chlorum & 0.2285 & 0.2186 & 0.2056 & 0.1946 & 0.1567 & & & & & & & & \\
\hline Chlorobium limicola & 0.2405 & 0.2345 & 0.2285 & 0.2285 & 0.2126 & 0.2026 & & & & & & & \\
\hline Chlorobium tepidum & 0.2395 & 0.2305 & 0.2236 & 0.2295 & 0.2086 & 0.2006 & 0.0240 & & & & & & \\
\hline Bacteroides fragilis & 0.2764 & 0.2675 & 0.2705 & 0.2655 & 0.2375 & 0.2365 & 0.2036 & 0.2056 & & & & & \\
\hline Rhodobacter capsulatus & 0.2525 & 0.2405 & 0.2345 & 0.2246 & 0.1996 & 0.1876 & 0.1946 & 0.1926 & 0.2295 & & & & \\
\hline Escherichia coli & 0.2345 & 0.2285 & 0.2345 & 0.2146 & 0.1836 & 0.1717 & 0.1896 & 0.1846 & 0.2365 & 0.1806 & 0.1697 & & \\
\hline Thermotoga maritima & 0.2206 & 0.2146 & 0.2375 & 0.1786 & 0.2086 & 0.1886 & 0.2066 & 0.2166 & 0.2315 & 0.2086 & 0.2056 & 0.1986 & \\
\hline Methanohalophilus mahii & 0.3743 & 0.3663 & 0.3772 & 0.3543 & 0.3713 & 0.3483 & 0.3623 & 0.3643 & 0.3683 & 0.3323 & 0.3323 & 0.3633 & 0.3134 \\
\hline
\end{tabular}

a See reference 31.

${ }^{h}$ Every site with a gap in any sequence was excluded from the analysis. The value for sequences that were different at every site was 1 ; all values were normalized to this value.

$57.1 \mathrm{~mol} \%$, respectively). However, the levels of genomic DNA hybridization between the new isolates and Chloroflexus aurantiacus are low (range, 9 to $18 \%$ ), which suggests that these organisms are not conspecific. In view of the phenotypic and genotypic data presented above, it is reasonable to conclude that our isolates should be classified as members of a new species of filamentous green bacteria. The remaining problem is the taxonomic relationship of the new isolates to Chloroflexus aurantiacus at the generic level. 16S rRNA gene sequence comparisons showed that the level of sequence similarity between strain MD- $66^{\mathrm{T}}$ and Chloroflexus aurantiacus is $92.8 \%$, which seems to be low enough to warrant placement in different genera from a phylogenetic viewpoint. However, we believe that at this time it is appropriate to classify the new isolates as members of a new Chloroflexus species, because

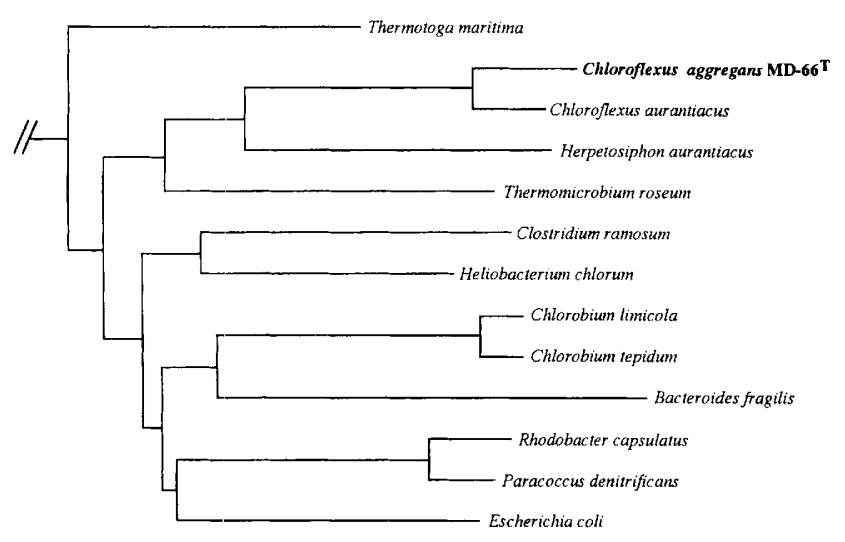

$10 \%$

FIG. 5. Phylogenetic position of Chloroflexus aggregans MD- $66^{\mathrm{T}}$ among eubacteria. The tree was constructed from the evolutionary distances shown in Table 3. Bar $=10$ nucleotide substitutions per 100 nucleotides in $16 \mathrm{~S}$ ribosomal DNA. An archaebacterial sequence (the Methanohalophilus mahii sequence) (Table 3) was used to root the tree. there are only a few phenotypic properties that could be used for generic separation.

On the basis of our phenotypic, genotypic, and phylogenetic data, we classify the new strains as members of a new Chloroflexus species, for which we propose the name Chloroflexus aggregans sp. nov.

Description of Chloroflexus aggregans sp. nov. Chloroflexus aggregans (ag'gre.gans. L. v. aggregare, to flock or band together; L. pres. part. aggregans, assembling, aggregating). Cells form unbranched multicellular filaments of indefinite length. The filaments are clearly septate. The diameters of cells range from 1.0 to $1.5 \mu \mathrm{m}$. Cells have no flagella but are motile by gliding. Gram negative. Cultures grow by forming mat-like aggregates in liquid that have the appearance of green balls. Cell aggregates reform rapidly whenever a culture is shaken to produce a uniform suspension under growth conditions. Photosynthetic cultures are green to greenish brown. Bacteriochlorophylls $a$ and $c$ are present in phototrophically grown cells (under anaerobic conditions) and to a certain extent in chemotrophically grown cells under aerobic conditions. Chlorosomes are present. The major carotenoid components are $\gamma$-carotene and $\mathrm{OH}-\gamma$-carotene glucoside fatty acid esters; there is also a trace amount of $\beta$-carotene.

Thermophilic facultative phototrophs that grow optimally at $55^{\circ} \mathrm{C}$. Aerobic growth in the dark occurs at full atmospheric oxygen tension. Thiamine and folic acid are required as growth factors. Good carbon sources are yeast extract and Casamino Acids. Simple organic compounds such as intermediates of the citric acid cycle, glutamate, and aspartate are utilized as sole carbon sources only under phototrophic conditions. The major quinone is menaquinone 10 . A trace amount of menaquinone 4 is also present.

Habitat: bacterial mats with cyanobacteria in freshwater of hot springs $\left(50\right.$ to $\left.67^{\circ} \mathrm{C}\right)$.

The $\mathrm{G}+\mathrm{C}$ content of the DNA is 56.7 to $57.0 \mathrm{~mol} \%$ (as determined by the HPLC method).

The type strain is strain MD-66 (= DSM 9485). 


\section{ACKNOWLEDGMENTS}

This work was supported by grants 05266215 (for Priority Areas) and 05640734 from the Ministry of Education, Science and Culture of Japan.

We thank Isao Uemura, Tokyo Metropolitan University, for technical instruction in electron microscopy; Shinichi Takaichi, Biological Laboratory, Nippon Medical School, for performing the analysis of carotenoids; and Tsunenori Nozawa, Tohoku University, Sendai, Japan, and John M. Olson, Odense University, Odense, Denmark, for providing bacterial strains.

\section{REFERENCES}

1. Cardoso, J. N., C. D. Watts, J. R. Maxwell, R. Goldfellow, G. Eglinton, and S. Golubic. 1978. A biogeochemical study of the Abu Dhabi algal mats: a simplified ecosystem. Chem. Geol. 23:273-291.

2. Cohen, Y. 1984. The Solar Lake cyanobacterial mats: strategies of photosynthetic life under sulfide, p. 23-38. In Y. Cohen, R. W. Castenholz, and H. O. Halvorson (ed.), Microbial mat: stromatolites. Alan R. Liss, Inc., New York.

3. D'Amelio, E. D., Y. Cohen, and D. J. Des Marais. 1989. Comparative functional ultrastructure of two hypersaline submerged cyanobacterial mats: Guerrero Negro, Baja California Sur, Mexico, and Solar Lake, Sinai, Egypt, p. 97-113. In Y. Cohen and E. Rosenberg (ed.), Microbial mats: physiological ecology of benthic microbial communities. American Society for Microbiology, Washington, D.C

4. Dubinina, G. A., and V. M. Gorlenko. 1975. New filamentous photosynthetic green bacteria containing gas vacuoles. Microbiology (Engl. Transl. Mikrobiologiya) 44:452-458.

5. Ezaki, T., S. Dejsirilert, H. Yamamoto, N. Takeuchi, and E. Yabuuchi. 1988. Simple and rapid genetic identification of Legionella species with photobiotin-labeled DNA. J. Gen. Appl. Microbiol. 34:191-199.

6. Fuller, R. C., and T. E. Redlinger. 1985. Light and oxygen regulation of the development of the photosynthetic apparatus in Chloroflexus, p. 155-162. In K. E. Steinbeck, S. Bonitz, C. J. Arntzen, and L. Bogorad (ed.), Molecular biology of the photosynthetic apparatus. Cold Spring Harbor Laboratory, Cold Spring Harbor, N.Y.

7. Giovannoni, S. J., N. P. Revsbech, D. M. Ward, and R. W. Castenholz. 1987. Obligately phototrophic Chloroflexus: primary production in anaerobic hot spring microbial mats. Arch. Microbiol. 147:80-87.

8. Gorlenko, V. M. 1976. Characteristics of filamentous phototrophic bacteria from freshwater lakes. Microbiology (Engl. Transl. Mikrobiologiya) 44:682684

9. Gorlenko, V. M., and T. A. Pivovarova. 1977. On the belonging of bluegreen alga Oscillatoria coenulescens Gicklhorn, 1921 to a new genus of chlorobacteria Oscillochloris nov. gen. Izv. Akad. Nauk SSSR Ser, Biol, 3:396-409.

10. Halfen, L. N., B. K. Pierson, and G. W. Francis. 1972. Carotenoids of a gliding organism containing bacteriochlorophylls. Arch. Microbiol. 82:240246.

11. Hanada, S., A. Hiraishi, K. Shimada, and K. Matsuura. 1995. Isolation of Chloroflexus aurantiacus and related thermophilic phototrophic bacteria from Japanese hot springs using an improved isolation procedure. J. Gen. Appl. Microbiol. 41:119-130.

12. Hiraishi, A. 1992. Direct automated sequencing of 16S rRNA amplified by polymerase chain reaction from bacterial cultures without DNA purification. Lett. Appl. Microbiol. 15:210-213.

13. Hiraishi, A., Y. Hoshino, and T. Satoh. 1991. Rhodoferax fermentans gen. nov., sp. nov., a phototrophic purple nonsulfur bacterium previously referred to as the "Rhodocyclus geratinosus-like" group. Arch. Microbiol. 155:330336

14. Hiraishi, A., Y. K. Shin, Y. Ueda, and J. Sugiyama. 1994. Automated sequencing of PCR-amplified 16S rRNA on 'Hydrolink' gels. J. Microbiol. Methods 19:145-154

15. Kellenberger, E., A. Ryter, and J. Sechand. 1958. Electron microscopic study of DNA-containing plasms. II. Vegetative and mature phage DNA as compared with normal bacterial nucleoids in different physiological states. J.
Biophys. Biochem. Cytol. 4:671-678.

16. Keppen, O. I. O. I. Baulina, and E. N. Kondratieva. 1994. Oscillochloris trichoides neotype strain DG-6. Photosynth. Res. 41:29-33.

17. Kushida, H. 1980. An improved embedding method using ERL 4206 and Quetol 653. J. Electron Microsc. 29:193-194.

18. Luft, J. H. 1964. Electron microscopy of cell extraneous coat as revealed by ruthenium red staining. J. Cell Biol. 23:54A.

19. Mack, E. E., and B. K. Pierson. 1988. Preliminary characterization of temperate marine member of the Chloroflexaceae, p. 237-241. In J. M. Olson, J. G. Ormerod, J. Amesz, E. Stackebrandt, and H. G. Trüper (ed.), Green photosynthetic bacteria. Plenum Publishing Corp., New York.

20. Madigan, M. T. 1976. Studies on the physiological ecology of Chloroflexus aurantiacus, a filamentous photosynthetic bacterium. Ph.D. thesis. University of Wisconsin, Madison.

21. Madigan, M. T., S. R. Peterson, and T. D. Brock. 1974. Nutritional studies on Chloroflexus, a filamentous photosynthetic, gliding bacterium. Arch. Microbiol. 100:97-103.

22. Marmur, J. 1961. A procedure for the isolation of deoxyribonucleic acid from micro-organisms. J. Mol. Biol. 3:208-218.

23. Oyaizu, H., B. Devrunner-Vossbrinck, L. Mandelko, J. A. Studier, and C. R Woese. 1987. The green non-sulfur bacteria: a deep branching in the eubacterial line of descent. Syst. Appl. Microbiol. 9:47-53.

24. Pfennig, N. 1989. Multicellular filamentous green bacteria, p. 1697-1707. In J. T. Staley, M. P. Bryant, N. Pfennig, and J. G. Holt (ed.), Bergey's manual of systematic bacteriology, vol. 3. Williams \& Wilkins, Baltimore.

25. Pierson, B. K., and R. W. Castenholz. 1971. Bacteriochlorophylls in gliding filamentous prokaryotes from hot springs. Nature (London) 223:25-27.

26. Pierson, B. K., and R. W. Castenholz. 1974. A phototrophic gliding filamentous bacterium of hot springs, Chloroflexus aurantiacus, gen. and sp. nov. Arch. Microbiol. 100:5-24.

27. Pierson, B. K., and R. W. Castenholz. Taxonomy and physiology of filamentous anoxygenic phototrophs. In R. E. Blankenship, M. T. Madigan, and C. E. Bauer (ed.), Anoxygenic photosynthetic bacteria, in press. Kluwer Dordrecht, The Netherlands.

28. Pierson, B. K., S. J. Giovannoni, and R. W. Castenholz. 1984. Physiological ecology of a gliding bacterium containing bacteriochlorophyll $a$. Appl. Environ. Microbiol. 47:576-584

29. Pierson, B. K., S. J. Giovannoni, D. A. Stahl, and R. W. Castenholz. 1985 Heliothrix oregonensis, gen. nov., sp. nov., a phototrophic filamentous gliding bacterium containing bacteriochlorophyll $a$. Arch. Microbiol. 142:164-167.

30. Pierson, B. K., D. Valdez, M. Larsen, E. Morgan, and E. E. Mack. 1994 Chloroflexus-like organisms from marine and hypersaline environments: distribution and diversity. Photosynth. Res. 41:35-52.

31. Saitou, N., and M. Nei. 1987. The neighbour joining method: a new method for reconstructing phylogenetic trees. Mol. Biol. Evol. 4:406-425.

32. Schmidt, K. 1980. A comparative study on the composition of chlorosomes (chlorobium vesicles) and cytoplasmic membranes from Chloroflexus aurantiacus strain OK-70-fl and Chlorobium limicola f. thiosulfatophilum strain 6230. Arch. Microbiol. 124:21-31.

33. Stolz, J. F. 1983. Fine structure of the stratified microbial community at Laguna Figueroa, Baja California, Mexico. I. Methods of in situ study of the laminated sediments. Precambrian Res. 20:479-492.

34. Stolz, J. F. 1984. Fine structure of the stratified microbial community at Laguna Figueroa, Baja California, Mexico. II. Transmission electron microscopy as a diagnostic tool in studying microbial community in situ, p. 23-38. In Y. Cohen, R. W. Castenholz, and H. O. Halvorson (ed.), Microbial mat: stromatolites. Alan R. Liss, Inc., New York.

35. Takaichi, S., and K. Shimada. 1992. Characterization of carotenoids in photosynthetic bacteria. Methods Enzymol. 213:374-385

36. Trüper, H. G. 1976. Higher taxa of the phototrophic bacteria Chloroflexaceae fam. nov., a family for the gliding, filamentous, phototrophic "green" bacteria. Int. J. Syst. Bacteriol. 26:74-75.

37. Venable, J. H., and R. Coggeshell. 1965. A simplified lead citrate stain for use in electron microscopy. J. Cell Biol. 25:407-408.

38. Woese, C. R. 1987. Bacterial evolution. Microbiol. Rev. 51:221-271. 